\title{
The neurological and ophthalmological manifestations of SPG4-related hereditary spastic paraplegia
}

\author{
Grant Guthrie - Gerald Pfeffer - Maura Bailie $\cdot$ Karen Bradshaw \\ Andrew C. Browning • Rita Horvath · Patrick F. Chinnery • \\ Patrick Yu-Wai-Man
}

Received: 23 October 2012/Accepted: 29 November 2012/Published online: 13 December 2012

(C) The Author(s) 2012. This article is published with open access at Springerlink.com

Dear Sirs,

The hereditary spastic paraplegias (HSPs) are a genetically heterogeneous group of disorders characterised by progressive corticospinal tract degeneration and the development of lower limb spasticity [1,2]. Autosomal-dominant HSP is the most commonly inherited form of the disease and in this group, SPG4 mutations account for $\sim 40 \%$ of cases [1]. The SPG4 gene codes for spastin, a critical neuronal protein that maintains organelle axonal transport by severing and rearranging the microtubule network [3, 4]. Dysfunctional mutant proteins or insufficient quantities of the wild-type protein inhibit this dynamic shuttling process resulting

Electronic supplementary material The online version of this article (doi:10.1007/s00415-012-6780-3) contains supplementary material, which is available to authorized users.

G. Guthrie - M. Bailie $\cdot$ K. Bradshaw - A. C. Browning ·

P. Yu-Wai-Man

Department of Ophthalmology, Royal Victoria Infirmary,

Newcastle upon Tyne, UK

G. Guthrie - G. Pfeffer · R. Horvath · P. F. Chinnery •

P. Yu-Wai-Man

Department of Neurology, Royal Victoria Infirmary,

Newcastle upon Tyne, UK

G. Pfeffer · R. Horvath · P. F. Chinnery · P. Yu-Wai-Man ( $₫)$

Wellcome Trust Centre for Mitochondrial Research, Institute of Genetic Medicine, Newcastle University,

Newcastle upon Tyne NE1 3BZ, UK

e-mail: Patrick.Yu-Wai-Man@ncl.ac.uk

K. Bradshaw

Department of Medical Physics, Royal Victoria Infirmary,

Newcastle upon Tyne, UK in axonal swelling and progressive retrograde degeneration that preferentially affects the long corticospinal axons [3, 4].

There is mounting evidence that the microtubule and mitochondrial networks are intrinsically linked at the cellular level [5]. This intriguing association has recently been highlighted by the clinical observation that autosomal-dominant optic atrophy (DOA) - a classical mitochondrial optic neuropathy caused by pathogenic OPAI mutations-can result in complicated neurological phenotypes $(\mathrm{DOA}+)$ with features indistinguishable from HSP [6]. Furthermore, subclinical corticospinal tract dysfunction also seems to be a prevalent feature among OPA1 mutation carriers presenting with isolated visual failure, suggesting a wider disease spectrum than originally considered [7]. Interestingly, these overlapping genotype-phenotype manifestations have been reported previously in families with a rarer, autosomal-recessive form of HSP caused by pathogenic SPG7 mutations, in which bilateral optic atrophy was a prominent feature segregating with spastic paraplegia [8-10]. Given the emerging disease mechanisms linking corticospinal tract dysfunction with optic nerve degeneration, the aim of this study was to determine the neurological and ophthalmological manifestations of SPG4-related HSP, looking specifically for evidence of clinical or subclinical optic neuropathy among affected patients. The overall neurological disability, including cognitive function, was also evaluated to provide a comprehensive assessment of the burden of disease in this group of patients.

A comprehensive neurological (GP, RH, PFC) and ophthalmological (PYWM) assessment (Supplementary Method) was carried out on ten white patients from the North of England harbouring confirmed pathogenic SPG4 mutations (Table 1). A broad spectrum of 
Table 1 Molecular genetic and ophthalmological features of the SPG4 patient cohort

\begin{tabular}{|c|c|c|c|c|c|c|c|c|}
\hline \multirow[t]{2}{*}{ Patient } & \multirow[t]{2}{*}{ Sex } & \multirow{2}{*}{$\begin{array}{l}\text { Age } \\
\text { (years) }\end{array}$} & \multicolumn{2}{|c|}{ SPG4 mutation } & \multirow{2}{*}{$\begin{array}{l}\text { BCVA } \\
\text { RE-LE }\end{array}$} & \multirow{2}{*}{$\begin{array}{l}\text { Optic discs/OCT } \\
\text { measurements }\end{array}$} & \multirow{2}{*}{$\begin{array}{l}\text { Eye } \\
\text { movements }\end{array}$} & \multirow{2}{*}{$\begin{array}{l}\text { Visual } \\
\text { electrophysiology }\end{array}$} \\
\hline & & & Exon & $\begin{array}{l}\text { cDNA change/ } \\
\text { consequence }\end{array}$ & & & & \\
\hline 1 & $\mathrm{~F}$ & 31 & 5 & c. $743 \mathrm{C}>\mathrm{G} / \mathrm{p} . \mathrm{S} 245 \mathrm{X}$ & $20 / 20-20 / 20$ & $\begin{array}{l}\text { Normal/no RNFL } \\
\text { thinning }\end{array}$ & Normal & Normal \\
\hline 2 & M & 53 & 5 & c. $743 \mathrm{C}>\mathrm{G} / \mathrm{p} . \mathrm{S} 245 \mathrm{X}$ & $20 / 20-20 / 20$ & $\begin{array}{l}\text { Normal/no RNFL } \\
\text { thinning }\end{array}$ & $\begin{array}{l}\text { Horizontal SWJ/ } \\
\text { saccadic pursuit }\end{array}$ & Normal \\
\hline 3 & $\mathrm{~F}$ & 50 & 6 & c.937delG/p.D313fsX1 & $20 / 20-20 / 20$ & $\begin{array}{l}\text { Normal/no RNFL } \\
\text { thinning }\end{array}$ & Normal & Normal \\
\hline 4 & $\mathrm{~F}$ & 55 & $4-17$ & $\begin{array}{l}\text { del exon 4-17/large-scale } \\
\text { deletion }\end{array}$ & $20 / 20-20 / 20$ & $\begin{array}{l}\text { Normal/no RNFL } \\
\text { thinning }\end{array}$ & Normal & Normal \\
\hline 5 & $\mathrm{~F}$ & 29 & 10 & $\begin{array}{l}\text { c.1253_1255delAAG/ } \\
\text { p.E418fsX198 }\end{array}$ & $20 / 20-20 / 20$ & $\begin{array}{l}\text { Normal/no RNFL } \\
\text { thinning }\end{array}$ & $\begin{array}{l}\text { Horizontal SWJ/ } \\
\text { saccadic pursuit }\end{array}$ & Normal \\
\hline 6 & $\mathrm{~F}$ & 25 & 11 & $\begin{array}{l}\text { c. } 1442 \_1443 \text { insA/ } \\
\text { p.V482fsX5 }\end{array}$ & $20 / 20-20 / 20$ & $\begin{array}{l}\text { Normal/no RNFL } \\
\text { thinning }\end{array}$ & Normal & Normal \\
\hline 7 & $\mathrm{~F}$ & 55 & 11 & $\begin{array}{l}\text { c.1442_1443insA/ } \\
\text { p.V482fsX5 }\end{array}$ & $20 / 20-20 / 20$ & $\begin{array}{l}\text { Normal/no RNFL } \\
\text { thinning }\end{array}$ & $\begin{array}{l}\text { Horizontal SWJ/ } \\
\text { saccadic pursuit }\end{array}$ & Normal \\
\hline 8 & $\mathrm{~F}$ & 49 & 11 & c. $1414 \mathrm{G}>\mathrm{A} / \mathrm{p} . \mathrm{V} 472 \mathrm{I}$ & $20 / 20-20 / 20$ & $\begin{array}{l}\text { Normal/no RNFL } \\
\text { thinning }\end{array}$ & Normal & Normal \\
\hline 9 & $\mathrm{~F}$ & 72 & 11 & c. $1384 \mathrm{~A}>\mathrm{G} / \mathrm{p} . \mathrm{K} 462 \mathrm{E}$ & $20 / 60-20 / 30$ & $\begin{array}{l}\text { Normal/no RNFL } \\
\text { thinning }\end{array}$ & Normal & Normal \\
\hline 10 & M & 65 & 11 & $\begin{array}{l}\text { c. } 1081 \mathrm{C}>\mathrm{A} ; \mathrm{c} .1082 \mathrm{~T}>\mathrm{A} / \\
\text { p.L361N }\end{array}$ & $20 / 20-20 / 20$ & $\begin{array}{l}\text { Normal/no RNFL } \\
\text { thinning }\end{array}$ & Normal & Normal \\
\hline
\end{tabular}

$B C V A$ best-corrected visual acuities, $c D N A$ complementary DNA, $L E$ left eye, $O C T$ optical coherence tomography, $R E$ right eye, $R N F L$ retinal nerve fibre layer, $S W J$ square wave jerks

neurological disability was observed among affected patients with scores ranging from one to nine on the modified EDSS scale (Table 2). Importantly, four patients had abnormal MOCA scores of less than 26 points. Seven patients performed poorly on the memory component of the MOCA test protocol and one patient had abnormal visuospatial/executive performance. The association between SPG4 mutations and progressive cognitive decline remains controversial [11-13] and our study of a well-characterised patient cohort provides further evidence favouring a true causal link. Two of the patients with abnormal MOCA scores were younger than the age of 30 years, clearly highlighting the need for clinical vigilance to detect early signs of cognitive impairment and to provide adequate level of support, especially to carers.

Except for one patient who had bilateral nuclear sclerotic cataracts, all patients had best-corrected visual acuities of 20/20 bilaterally (Table 1). The ophthalmological examination was normal with full colour discrimination and no detectable optic disc or retinal abnormalities. Visual fields, RNFL thickness measurements and visual electrophysiology were within the normal range for the entire HSP patient cohort. Three patients had abnormal eye movements with horizontal square wave jerks and saccadic smooth pursuits. No significant ptosis or limitation of eye movements was noted on orthoptic assessment. Based on our comprehensive clinical and electrophysiological evaluation, visual loss secondary to optic nerve or retinal degeneration is unlikely to be a major phenotypic manifestation of SPG4-related disease. Affected patients and atrisk family members can therefore be reassured that unlike other genetically-determined forms of HSP [6-10], SPG4 mutations are not associated with the development of significant ophthalmological complications, in particular visual failure. 


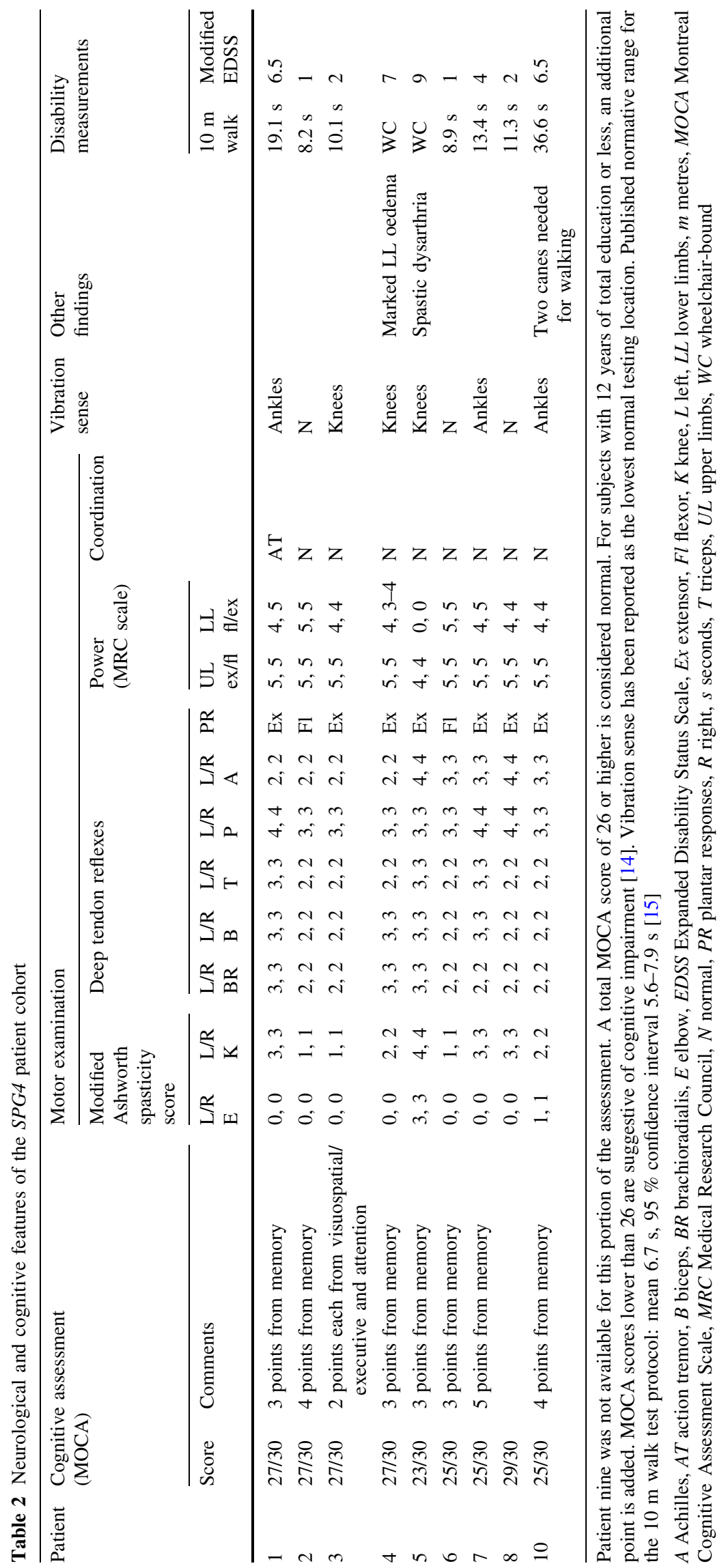


Acknowledgments This work was supported by a research grant from the Association of British Neurologists (ABN, UK). GP is the recipient of a Bisby Fellowship from the Canadian Institutes of Health Research. RH is supported by the Medical Research Council (MRC, UK). PFC is a Wellcome Trust Senior Fellow in Clinical Science and a UK National Institute of Health Research (NIHR) Senior Investigator who also receives funding from the MRC (UK), and the UK NIHR Biomedical Research Centre for Ageing and Age-related disease award to the Newcastle upon Tyne Hospitals NHS Foundation Trust. PYWM is an MRC (UK) Clinician Scientist.

Conflicts of interest All the listed authors in this manuscript report no relevant financial disclosures or conflicts of interest.

Ethical standard This study had the relevant institutional ethical approval and it was carried out in compliance with the Declaration of Helsinki.

Open Access This article is distributed under the terms of the Creative Commons Attribution License which permits any use, distribution, and reproduction in any medium, provided the original author(s) and the source are credited.

\section{References}

1. Salinas S, Proukakis C, Crosby A, Warner TT (2008) Hereditary spastic paraplegia: clinical features and pathogenetic mechanisms. Lancet Neurol 7:1127-1138

2. Harding AE (1983) Classification of the hereditary ataxias and paraplegias. Lancet 1:1151-1155

3. McDermott CJ, Grierson AJ, Wood JD et al (2003) Hereditary spastic paraparesis: disrupted intracellular transport associated with spastin mutation. Ann Neurol 54:748-759
4. Lumb JH, Connell JW, Allison R, Reid E (2012) The AAA ATPase spastin links microtubule severing to membrane modelling. Biochim Biophys Acta 1823:192-197

5. Schon EA, Przedborski S (2011) Mitochondria: the next (Neurode) generation. Neuron 70:1033-1053

6. Yu-Wai-Man P, Griffiths PG, Gorman GS et al (2010) Multisystem neurological disease is common in patients with OPA1 mutations. Brain 133:771-786

7. Baker MR, Fisher KM, Whittaker RG, Griffiths PG, Yu-Wai-Man P, Chinnery PF (2011) Subclinical multisystem neurologic disease in "pure" Opa1 autosomal dominant optic atrophy. Neurology 77:1309-1312

8. Casari G, De Fusco M, Ciarmatori S et al (1998) Spastic paraplegia and OXPHOS impairment caused by mutations in paraplegin, a nuclear-encoded mitochondrial metalloprotease. Cell 93:973-983

9. Wilkinson PA, Crosby AH, Turner C et al (2004) A clinical, genetic and biochemical study of SPG7 mutations in hereditary spastic paraplegia. Brain 127:973-980

10. van Gassen KL, van der Heijden CD, de Bot ST et al (2012) Genotype-phenotype correlations in spastic paraplegia type 7: a study in a large Dutch cohort. Brain 135:2994-3004

11. Tallaksen CME, Guichart-Gomez E, Verpillat P et al (2003) Subtle cognitive impairment but no dementia in patients with spastin mutations. Arch Neurol 60:1113-1118

12. McMonagle P, Byrne P, Hutchinson M (2004) Further evidence of dementia in SPG4-linked autosomal dominant hereditary spastic paraplegia. Neurology 62:407-410

13. Murphy S, Gorman G, Beetz C et al (2009) Dementia in SPG4 hereditary spastic paraplegia Clinical, genetic, and neuropathologic evidence. Neurology 73:378-384

14. Nasreddine ZS, Phillips NA, Bedirian V et al (2005) The montreal cognitive assessment, MoCA: a brief screening tool for mild cognitive impairment. J Am Geriatr Soc 53:695-699

15. Watson M (2002) Refining the ten-metre walking test for use with neurologically impaired people. Physiotherapy 88:386-397 